\title{
Prediction of Skin Sensitization Potential of Silver and Zinc Oxide Nanoparticles Through the Human Cell Line Activation Test
}

\author{
Ravi Gautam ${ }^{1}$, SuJeong Yang ${ }^{1}$, Anju Maharjan ${ }^{1}$, JiHun Jo ${ }^{1}$, Manju Acharya ${ }^{1}$, Yong Heo ${ }^{1,2 *}$ \\ and ChangYul Kim ${ }^{2 *}$
}

${ }^{1}$ Department of Occupational Health, College of Bio and Medical Sciences, Daegu Catholic University, Gyeongsan, South Korea, ${ }^{2}$ Department of Toxicity Assessment, The Graduate School of Medical and Health Industry, Daegu Catholic University, Gyeongsan, South Korea

OPEN ACCESS

Edited by:

Eui Bae Jeung,

Chungbuk National University,

South Korea

Reviewed by:

Robert Landsiedel,

BASF, Germany

Kyung-Min Lim,

Ewha Womans University,

South Korea

Susun An,

Amorepacific, South Korea

*Correspondence:

ChangYul Kim

cykim0813@cu.ac.kr

Yong Heo

yheo@cu.ac.kr

Specialty section:

This article was submitted to

In Vitro Toxicology,

a section of the journal

Frontiers in Toxicology

Received: 05 January 2021

Accepted: 26 April 2021

Published: 28 May 2021

Citation:

Gautam R, Yang S, Maharjan A, Jo J, Acharya M, Heo Y and Kim C (2021)

Prediction of Skin Sensitization

Potential of Silver and Zinc Oxide

Nanoparticles Through the Human

Cell Line Activation Test.

Front. Toxicol. 3:649666.

doi: 10.3389/ftox.2021.649666
The development of nanotechnology has propagated the use of nanoparticles (NPs) in various fields including industry, agriculture, engineering, cosmetics, or medicine. The use of nanoparticles in cosmetics and dermal-based products is increasing owing to their higher surface area and unique physiochemical properties. Silver (Ag) NPs' excellent broad-spectrum antibacterial property and zinc oxide (ZnO) NPs' ability to confer better ultraviolet (UV) protection has led to their maximal use in cosmetics and dermal products. While the consideration for use of nanoparticles is increasing, concerns have been raised regarding their potential negative impacts. Although used in various dermal products, $\mathrm{Ag}$ and ZnO NPs' skin sensitization (SS) potential has not been well-investigated using in vitro alternative test methods. The human Cell Line Activation Test (h-CLAT) that evaluates the ability of chemicals to upregulate the expression of CD86 and CD54 in THP-1 cell line was used to assess the skin sensitizing potential of these NPs. The h-CLAT assay was conducted following OECD TG 442E. NPs inducing relative fluorescence intensity of CD86 $\geq 150 \%$ and/or CD54 $\geq 200 \%$ in at least two out of three independent runs were predicted to be positive. Thus, Ag (20,50, and $80 \mathrm{~nm}) \mathrm{NPs}$ and $\mathrm{ZnO}$ NPs were all predicted to be positive in terms of SS possibility using the h-CLAT prediction model. Although further confirmatory tests addressing other key events (KES) of SS adverse outcome pathway (AOP) should be carried out, this study gave an insight into the need for cautious use of Ag and ZnO NPs based skincare or dermal products owing to their probable skin sensitizing potency.

Keywords: skin sensitization, nanoparticles, silver, zinc oxide, human cell line activation test (h-CLAT)

\section{INTRODUCTION}

The development of nanotechnology has spread the use of nanoparticles (NP) in various fields including industry, agriculture, engineering, cosmetics, or medicine. The cosmetic industry is among the first industry to implement nanotechnology-based materials (Mihranyan et al., 2012). For more than 30 years, nano-based ingredients have been used in the cosmetic industry (Pastrana et al., 2018; Carrouel et al., 2020). Nanomaterials based topical medicines or cosmetics render special benefits over micro-scale materials. The higher surface area and unique physiochemical 
properties of nanoparticles lead to higher transport of ingredients through the skin (Ahmad et al., 2018; Fytianos et al., 2020). The key goals of using nanoparticles in skincare products are controlled release of ingredients, increased efficacy, occlusive properties, physical stability, or active transport of targeting (Kaul et al., 2018).

It is claimed that among various nanoparticles used in consumer products, silver nanoparticles (Ag NPs) hold the highest degree of commercialization (Henig, 2007) and Ag NPs are incorporated in $30 \%$ of products that contain nanomaterials (Wijnhoven et al., 2009). Ag NPs' excellent broad-spectrum antibacterial properties and minimal side effects have led their use in detergents, bandages, catheters, antibacterial sprays, shoes, food storage containers, clothing, water disinfectants, etc (Vigneshwaran et al., 2007; Crosera et al., 2009; Augustine et al., 2016; Khan et al., 2018). AgNPs are applied in nanocomposites, anti-caries formulations, implant coatings, treatment of oral cancer and local anesthesia in dentistry (Noronha et al., 2017). Furthermore, AgNPs' role in cancer diagnosis, cancer treatment, cardiovascular implants, orthopedic and orthodontic implants and fixations, and as antimalarial agents is increasing their use in the medical field as well (Murphy et al., 2015; Rai et al., 2017; Huy et al., 2019). Owing to their useful properties, zinc oxide $(\mathrm{ZnO})$ nanostructures have attracted a great deal of interest for novel applications in cosmetics, pigments and coatings, biomedical imaging, drug delivery, antibacterial agents, catalysts, diabetic treatment, wound healing, anti-cancer or anti inflammatory agent (Zhang et al., 2013; Shi et al., 2014; Kim S. et al., 2017; Mishra et al., 2017). ZnO NPs have also been used to enhance flame retardancy and thermal stability in textile fabrics, as well as moisture management, thermal insulation, electrical conductivity, and hydrophobicity (Verbič et al., 2019). ZnO NPs render significant bactericidal properties and are thus used as an antimicrobial agent in food industries (Seil and Webster, 2012; Sirelkhatim et al., 2015). Also, ZnO NPs are consistently used in sunscreens to confer better ultraviolet (UV) protection and to make products transparent and aesthetically acceptable compared to their larger opaque counterparts (Cross et al., 2007; Wang and Tooley, 2011). According to a survey in 2012, ZnO was used in 235 domestic cosmetic products of Korea with concentrations of $0.05-17 \%$ and powder type products were highest among the cosmetic containing $\mathrm{ZnO}$ (Kim K. B. et al., 2017).

While consideration in the use of nanoparticles is increasing, concerns have been raised regarding their potential impact on human health. The larger surface area of NPs offers larger numbers of atoms or molecules leading to higher reactivity. $\mathrm{ZnO}$ NPs showed lower TC-50 (concentration inducing 50\% cell mortality) in THP-1 cells than its micron-sized and also showed higher toxicity in human $\mathrm{T}$ cells (Prach et al., 2013; Sahu et al., 2016). Similarly, another study screening the toxicity of nano and micro sized silver in human hepatocyte cell lines depicted that AgNP showed significantly higher toxicity than micro-Ag (Liu et al., 2011). Regarding the dermal exposure of nanoparticles, it has been previously reported that metallic NPs can pass through the stratum corneum, hair follicles, and sebaceous glands (Rancan et al., 2012). ZnO nanoparticles penetrated the stratum corneum of sunburned pig and hairless mice and led to collagen loss in rats applied with sunscreen containing $20 \mathrm{~nm} \mathrm{ZnO}$ for 28 days (Wu et al., 2009; Osmond and McCall, 2010; Monteiro-Riviere et al., 2011; Surekha et al., 2012). In studies, sunscreen containing ZnO NPs and microparticles applied to human subjects resulted in a higher measurable concentration of zinc in blood and urine of the subjects who were exposed to $\mathrm{ZnO}$ NP-containing products than the product with $\mathrm{ZnO}$ microparticles (Gulson et al., 2010, 2012). Similarly, $\mathrm{Ag}$-NPs are reported to penetrate intact skin with increased permeation through damaged skin (Larese et al., 2009). Since $\mathrm{ZnO}$ and Ag NPs penetrate the skin, their interaction with skin proteins and immune cells could potentially lead to cutaneous immune reactions including skin sensitization (Grundström and Borrebaeck, 2019). Although various assessments related to $\mathrm{ZnO}$ and Ag NPs' toxicities have been performed, skin sensitizing potential remains unexplored.

Skin sensitization (SS) consists of a type IV hypersensitivity response triggered after repeated dermal exposure to a possible allergenic substance in susceptible individuals. Every manufactured commercial product must be evaluated for its skin sensitizing potential, however, the use of animals for testing skin sensitizing potential has been prohibited by European Union (EU) regulations (European Commission, 2006; Chung et al., 2018). Various alternative test methods have been adopted by the Organization for Economic Co-operation and Development (OECD) to measure if a chemical ingredient causes a key event (KE) on the adverse outcome pathway (AOP) for SS. According to the OECD, the AOP for SS has been divided into four KEs: interaction of chemicals with skin proteins and formation of the hapten-protein complex (KE-1 or molecular initiating event, MIE), inflammatory keratinocytes response (KE-2), activation of dendritic cells (KE-3) and activation and proliferation of T-lymphocytes (KE-4) (OECD, 2014). Among various OECD adopted methods, TG 422E deals with the in vitro skin sensitizations assays addressing the key events on activation of dendritic cells on the AOP for SS. It consists of the human Cell Line Activation Test (h-CLAT), the U937 cell line activation test, and the interleukin-18 reporter gene assay (OECD, 2018). Of these three methods, h-CLAT evaluates the ability of chemicals to upregulate the expression of dendritic cell activation markers (CD86 and CD54) in THP-1 cells, a human monocytic leukemia cell line. The h-CLAT method has been shown to possess $85 \%$ accuracy $(n=142)$ in distinguishing skin sensitizers from non-sensitizers with a sensitivity of $93 \%$ and specificity of $66 \%$ compared to local lymph node assay (LLNA) results (OECD, 2018). Moreover, this method has been successfully employed to predict the skin sensitizing potential of biocides: polyhexamethylene guanidine (PHMG) and triclosan (TCS) with or without excipient propylene glycol (PG) producing consistent results as obtained using local lymph node assay: 5-bromo-2-deoxyuridine-flow cytometry method (LLNA: BrdU-FCM) (Joo et al., 2019; Yang et al., 2021). This method has also been employed to screen the skin sensitizing potential of biodegradable polymers, carbon nanohorns (CNHs), and hydroxyethylcellulose (HEC) nanofibers (Jung et al., 2011; Selvam et al., 2020). 
Different in vitro assays to differentiate between skin sensitizers and non-sensitizers have been carried out. A study investigated single-walled carbon nanotubes, titanium dioxide, and fullerene nanomaterials using MDPRA and U-SENS ${ }^{\mathrm{TM}}$ and categorized them as skin sensitizers through combined results of the assays (Bezerra et al., 2021). Using OECD adopted, the ARE-Nrf2 Luciferase KeratinoSens ${ }^{\text {TM }}$, representing the second key event of AOP for SS, nanoparticles such as copper oxide $(\mathrm{CuO})$, cobalt monoxide $(\mathrm{CoO})$, cobalt oxide $\left(\mathrm{Co}_{3} \mathrm{O}_{4}\right)$, nickel oxide $(\mathrm{NiO})$, and titanium oxide $\left(\mathrm{TiO}_{2}\right)$ were tested to classify $\mathrm{CuO}$ and $\mathrm{CoO}$ as skin sensitizers (Kim et al., 2021b). Similarly, other studies using the same method predicted $\mathrm{CuO}$ as sensitizer and carbon nanotubules as non-sensitizer (Kim et al., 2020, 2021a). Yoshioka et al. highlighted the indirect mechanism of skin sensitization by metal nanoparticles where nanoparticles presented metal ions to lymph nodes and induction of metal ion-specific $\mathrm{CD}^{+} \mathrm{T}$ cells and production of IL-17 led to skin sensitization or allergic response (Yoshioka et al., 2017). Activated dendritic cells play a crucial role in priming specific $\mathrm{T}$ cell response and h-CLAT assay addresses the process of activation of dendritic cells following exposure to sensitization. Data on the use of h-CLAT to screen the skin sensitizing potential of nanoparticles is little and successful application of this method could aid on discrimination of NP's skin sensitizing property. This present study used the h-CLAT to predict the skin sensitizing potential of $\mathrm{ZnO}$ and $\mathrm{Ag}$ NPs, which are consistently used in the commercial products that are exposed to skin. Although there are restrictions on testing insoluble substances using an in vitro alternative test methods for prediction of skin sensitization, few insoluble materials and nanoparticles have been evaluated by KeratinoSens ${ }^{\mathrm{TM}}$ assay or ARE-Nrf2 Luciferase-Keratinosens $^{\mathrm{TM}}$ assay (Andres et al., 2013; Settivari et al., 2015; Kim et al., 2020, 2021a). Furthermore, OECD TG 422E recommends using a stable suspension of substances with lower or no solubility. Thus, this study could present an insight into whether the use of nanoparticles in commercial dermal or skincare products is rational or precautions need to be taken.

\section{MATERIALS AND METHODS}

\section{Test Chemicals and Preparation of NP Suspension}

Eight substances were used for the proficiency test for the h-CLAT described in OECD TG442E Appendix II (OECD, 2018) as follows: nickel sulfate (CASRN 10101-97-0), 2mercaptobenzothiazole (CASRN 149-30-4), R(+)-Limonene (CASRN 5989-27-5), imidazolidinyl urea (CASRN 39236-46-9), isopropanol (CASRN 67-63-0), glycerol (CASRN 56-81-5), lactic acid (CASRN 50-21-5), 4-aminobenzoic acid (CASRN 150-13$0)$. All the chemicals were purchased from Sigma-Aldrich (St. Louis, Missouri, USA) except nickel sulfate (Alfa Aesar, Ward hill, Massachusetts, USA). All the chemicals were coded and provided to the experimenter. The experimenter had no idea about the chemical's identifications. 2,4-dinitrochlorobenzene (DNCB, CASRN 97-00-7) was used as a positive control in every assay carried out. Two independent experiments were performed for the proficiency test chemicals since the two runs were concordant on defining as positive or negative, and therefore a third run was not necessary.

Zinc Oxide powder (water dispersion, 20 weight\%; size: $30 \sim 40 \mathrm{~nm}$ ) was purchased from US Research Nanomaterials, Inc (Houston, TX, USA) and 20, 50, and $80 \mathrm{~nm}$ silver nanosphere (silver purity $99.99 \%, 1.03,1.08$, and $1.04 \mathrm{mg} / \mathrm{ml}$ respectively in aqueous $2 \mathrm{mM}$ citrate) were purchased from nanoComposix (San Diego, CA, USA).

The suspension of NPs in media were prepared as described by Kim et al. with few modifications (Kim et al., 2021a). Saline was used as a vehicle for the dispersion of nanoparticles. Stock solutions prepared in saline were sonicated at $40 \mathrm{kHz}$ with $100 \mathrm{~W}$ output power for $10 \mathrm{~min}$ in a bath-type sonicator (KODO, Gyeonggi-do, Korea). Then, the stock solutions were diluted to different working concentrations (1:50 dilution) using RPMI supplemented with $10 \%$ FBS followed by short sonication for $2 \mathrm{~min}$. The dispersion of NPs in media was checked under the microscope and no further characterization was carried out.

\section{Cell Culture}

The cell culture procedures generally followed the ECVAM Good Cell Culture Guidelines and the techniques have been already addressed in the previous report (Hartung et al., 2002; Coecke et al., 2005; Lee et al., 2019). The THP-1 cell line was purchased from American Type Culture Collection (Manassas, VA, USA) and cultured in RPMI-1640 with L-glutamine and 25 mM HEPES (Gibco, Waltham, MA, USA) supplemented with 10\% fetal bovine serum (Gibco), $0.05 \mathrm{mM}$ 2-mercaptoethanol (SigmaAldrich) and $1 \%$ penicillin-streptomycin mixture (Gibco). The cells were considered suitable for h-CLAT assay as their doubling time was $38 \mathrm{~h}$ which is within the range $(30-55 \mathrm{~h})$ defined in DBALM Protocol $\mathrm{n}^{\circ} 158$ and the reactivity check with DNCB, nickel sulfate, and DMSO provided expected results, as detailed in the OECD TG 442E (OECD, 2018) and the DB-ALM Protocol $\mathrm{n}^{\circ} 158$ : human Cell Line Activation Test (h-CLAT) (EURL-ECVAM, 2016). In this study, the relative fluorescence intensity (RFI, \%) for CD86 and CD54 with $4 \mu \mathrm{g} / \mathrm{ml} \mathrm{DNCB}$ were 611 and $426 \%$; $200 \mu \mathrm{g} / \mathrm{ml}$ nickel sulfate were 290 and $2,195 \%$, and $2,000 \mu \mathrm{g} / \mathrm{ml}$ lactic acid were 117 and $138 \%$ respectively. The cell viability of (0.2\%) DMSO or media vehicle control was $95-98 \%$.

\section{h-CLAT Assay}

All the procedures followed the OECD TG 422E and DB-ALM protocol $\mathrm{n}^{\circ} 158$. First, dose-finding assays were performed. In this assay, the concentration that maintained $75 \%$ cell viability (CV75) compared to the vehicle control (culture media) was calculated. For this, THP- 1 cells $\left(10^{6}\right.$ cells) were cultured with $1 \mathrm{ml}$ of various concentrations of nanoparticles in 24 well plate and incubated for $24 \mathrm{~h}$ at $37^{\circ} \mathrm{C}$ in a $5 \% \mathrm{CO}_{2}$ incubator. Eight different two-fold diluted concentrations of nanoparticles were used. Concentrations ranged from 1,000 to $7.8 \mu \mathrm{g} / \mathrm{ml}$ for $\mathrm{ZnO} \mathrm{NPs}$ and concentrations for 20,50 , and $80 \mathrm{~nm} \mathrm{Ag}$ NPs ranged from 20.8 to $0.163 \mu \mathrm{g} / \mathrm{ml}, 21.6$ to $0.169 \mu \mathrm{g} / \mathrm{ml}$ and 20.8 to $0.163 \mu \mathrm{g} / \mathrm{ml}$, respectively. Two independent runs were carried out to determine the average CV75. Cell viability was determined by fluorescence-activated cell sorting (FACS) 
analysis (BD ACCURI ${ }^{\mathrm{TM}}$, BD Bioscience, San Jose, CA, USA) using propidium iodide (PI, Sigma-Aldrich) staining at the concentration of $0.25 \mu \mathrm{g} / \mathrm{FACS}$ tube.

To derive a single prediction of whether a substance is positive in terms of surface markers expression, three independent experiments for NPs were performed and the h-CLAT test method prediction model was applied. For the experiments, THP- 1 cells $\left(10^{6}\right)$ were incubated with eight serial concentrations $\left(1.2 \times\right.$ CV75, CV75, 1/1.2 × CV75, 1/1.2 $2^{2}$ CV75, $1 / 1.2^{3} \times$ CV75, 1/1.2 $2^{4}$ CV75, $1 / 1.2^{5} \times$ CV75, 1/1.2 $2^{6} \times$ CV75). DNCB $(4 \mu \mathrm{g} / \mathrm{ml})$ was used as positive control and $0.2 \%$ DMSO was used as its vehicle control. After $24 \mathrm{~h}$ of incubation, cells were washed twice with FACS buffer followed by blocking with FACS buffer containing $0.01 \%$ globulin solution (Cohn fraction II, III human, Sigma-Aldrich) at $4^{\circ} \mathrm{C}$ for $15 \mathrm{~min}$. Then cells were split into three aliquots in round-bottom polystyrene tubes and stained with FITC labeled anti-CD86 (BD-Pharmingen), antiCD54 (Dako, Denmark), or mouse IgG1 isotype control (Dako) antibodies at $4^{\circ} \mathrm{C}$ for $30 \mathrm{~min}$. After washing two times with FACS buffer, cells were suspended in FACS buffer and PI was added before cell acquisition by flow cytometer. The Relative fluorescence intensity of CD86 and CD54 was calculated based on mean fluorescence intensity (MFI). An additional experiment to rule out the possibility of fluorescence interference due to nanoparticles was carried out, for this, nanoparticles at working concentrations in the absence of cells were checked for their FITC fluorescence compared to non-stained cells.

\section{Decision of Skin Sensitizing Positivity}

In h-CLAT, a substance was predicted as positive if, in at least 2 of 3 independent experiments, any tested concentrations yielded CD86 or CD54 RFIs of $\geq 150 \%$, or $\geq 200 \%$ (CV $\geq 50 \%$ ), respectively. After a substance was predicted to be positive, the effective concentration (EC) for CD86 and/ or CD54 expression was calculated as described in the OECD TG 442E. The EC150 for CD86 and the EC200 for CD54 are the concentrations at which the test substance induced an RFI of 150 or $200 \%$, respectively.

\section{RESULTS}

\section{Proficiency Test and Cell Viability}

The proficiency test was performed to demonstrate the technical proficiency of the h-CLAT before its routine use. All eight tested substances were correctly categorized as positive or negative by h-CLAT. Nickel sulfate, 2-mercaptobenzothiazole, $\mathrm{R}(+)$-limonene, and imidazolidinyl urea were correctly classified as positive while isopropanol, glycerol, lactic acid, and 4aminobenzoic acid were classified as negative (Table 1). The proficiency variables of four sensitizers (CV75, EC150, EC200) fell into the reference ranges provided in OECD TG 422E. Even though according to OECD TG 422E, CD86 RFI value for 2-mercaptobenzothiazole and $\mathrm{R}(+)$-limonene is negative, here both the chemicals demonstrated CD86 RFI more than $150 \%$. Moreover, EC values are within the reported reference range in case of positive results. CV75s were determined for all four NPs. No cell toxicity was observed for 20, $50 \mathrm{~nm}$, and $80 \mathrm{~nm} \mathrm{Ag} \mathrm{NPs}$ at tested concentrations and the highest treated concentrations were considered to be CV75 of the respective NPs. In the case of $\mathrm{ZnO}, 25.8 \mu \mathrm{g} / \mathrm{ml}$ was determined as the average CV75 of two independent assays (Table 2).

\section{Prediction of the Skin Sensitizing Potential of Silver and Zinc Oxide Nanoparticles}

Three independent runs were performed to screen 20,50, and $80 \mathrm{~nm} \mathrm{Ag}$ and ZnO NPs. According to the OECD TG 422E, hCLAT predicts that a substance is positive if in two runs the CD86 $\mathrm{RFI}$ is $\geq 150 \%$ and/or the CD54 RFI is $\geq 200 \%$ (with CV $\geq 50 \%$ ) at any tested concentration (OECD, 2018). All the acceptance criteria were met for the h-CLAT assay, RFI for CD86 and CD54 with $4 \mu \mathrm{g} / \mathrm{ml}$ DNCB were $>150$ and $>200 \%$ respectively with average cell viability of $80-86 \%$. The average cell viability of $(0.2 \%)$ DMSO and media ranged from 95 to $98 \%$ and the cell viability for all the tested concentration of NPs were higher than 50\%. All CD86 RFI (Figure 1) and CD54 RFI (Figure 2) of different concentration of NPs are considered to be actual RFI of CD86 and CD54 expressed by THP-1 cells and not due to the interference of nanoparticles as each CD86 RFI and CD54 RFI was obtained after reducing the MFI of isotype for their respective concentrations. Moreover, the $\lambda \max$ for $\mathrm{ZnO} N \mathrm{NP}$, $20 \mathrm{~nm}$ Ag NPs, 50, and $80 \mathrm{~nm}$ NPs were 335, 391, 424, and $455 \mathrm{~nm}$, according to the manufacturer's information and do not coincide with FITC fluorescence. Moreover, nanoparticles did not give FITC fluorescence when tested in absence of cells and antibody staining. All four nanoparticles were predicted to be positive with only $50 \mathrm{~nm}$ silver classified as negative in one run (Table 2). The final average EC value was calculated using EC150 or EC200 values of positive tests among three independent tests. EC150 and EC200 of $20 \mathrm{~nm} \mathrm{Ag}$ were 14 and $12 \mu \mathrm{g} / \mathrm{ml}$, of $50 \mathrm{~nm}$ Ag were 8 and $7 \mu \mathrm{g} / \mathrm{ml}$, of $80 \mathrm{~nm} \mathrm{Ag}$ were 14 and $9 \mu \mathrm{g} / \mathrm{ml}$ and of zinc oxide were 11 and $11 \mu \mathrm{g} / \mathrm{ml}$.

\section{DISCUSSION}

Increasing use of nanoparticles in cosmetics or dermal-based products has escalated nanoparticle exposure in the workforce or customers. Despite their tremendous potential benefits, little is understood about the short-term or long-term health effects. Concerns have been raised about the potential risks that could result from the skin penetration of nanoparticles after application in the form of cosmetics or other dermal products. Skin sensitization is a key endpoint for the safety evaluation of chemicals in cosmetics and personal care products (Settivari et al., 2017). However, the skin sensitization potential of nanoparticles used in various consumer products is the least studied. Thus, in this study, we employed the h-CLAT assay to predict the skin sensitization potential of $\mathrm{ZnO}$ and $\mathrm{Ag}$ NPs. $\mathrm{ZnO}$ and Ag NPs independent of their size were predicted to be skin sensitizers based on the h-CLAT prediction model outcomes. Induction of cell membrane markers, CD86 and CD54, in this study is believed to be due to NPs' intrinsic property and not related to the dispersion vehicles. ZnO NPs were dispersed in water and AgNPs were dispersed in $2 \mathrm{mM}$ sodium citrate which was further diluted at least 50 times to prepare working 
TABLE 1 | Proficiency test results of eight recommended substance in the OECD TG 442E for h-CLAT assay.

\begin{tabular}{|c|c|c|c|c|c|c|c|c|}
\hline \multirow[t]{2}{*}{ Test substances $^{a}$} & \multirow{2}{*}{$\begin{array}{l}\text { In vivo } \\
\text { prediction }\end{array}$} & \multirow{2}{*}{$\begin{array}{c}\text { CV75 } \\
\text { reference } \\
\text { range } \\
(\mu \mathrm{g} / \mathrm{ml})\end{array}$} & \multirow{2}{*}{$\begin{array}{l}\text { TG 442E results } \\
\text { for CD86 (EC } 150 \\
\text { reference range } \\
\text { in } \mu \mathrm{g} / \mathrm{ml} \text { ) }\end{array}$} & \multirow{2}{*}{$\begin{array}{l}\text { TG 442E results } \\
\text { for CD54 (EC200 } \\
\text { reference range } \\
\text { in } \mu \mathrm{g} / \mathrm{ml})\end{array}$} & \multicolumn{4}{|c|}{ Results (1st run, 2nd run) and prediction } \\
\hline & & & & & $\begin{array}{c}\text { CV75 } \\
(\mu \mathrm{g} / \mathrm{ml})^{b}\end{array}$ & 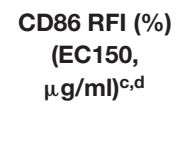 & $\begin{array}{c}\text { CD54 RFI (\%) } \\
\text { (EC200, }^{\mu \mathrm{g} / \mathrm{ml})^{\mathrm{c}, \mathrm{d}}}\end{array}$ & $\begin{array}{c}\text { + Prediction } \\
\text { (CD86 } \geq 150 \% \\
\text { and/or CD54 } \geq \\
200 \%)\end{array}$ \\
\hline Nickel sulfate & S (moderate) & $30-500$ & $+(<100)$ & $+(10-100)$ & 218,162 & $371,262(46)$ & $2,423,1,829(51)$ & + \\
\hline 2-Mercaptobenzothiazole & S (moderate) & $30-400$ & $-(>10)^{e}$ & $+(10-140)$ & 166,160 & $510,233(85)$ & $526,752(59)$ & + \\
\hline $\mathrm{R}(+)$-Limonene & S (weak) & $>20$ & $-(>5)^{e}$ & $+(<250)$ & 180,376 & 144,473 (239) & $254,1,012(121)$ & + \\
\hline Imidazolidinyl urea & S (weak) & $25-100$ & $+(20-90)$ & $+(20-75)$ & 37,42 & $462,214(42)$ & $690,463(31)$ & + \\
\hline Isopropanol & NS & $>5,000$ & $-(>5,000)$ & $-(>5,000)$ & $>1,000$ & $97,114(\mathrm{~N} / \mathrm{A})$ & 153, $176(\mathrm{~N} / \mathrm{A})$ & - \\
\hline Glycerol & NS & $>5,000$ & $-(>5,000)$ & $-(>5,000)$ & $>1,000$ & $139,72(\mathrm{~N} / \mathrm{A})$ & $132,122(\mathrm{~N} / \mathrm{A})$ & - \\
\hline Lactic acid & NS & $1,500-5,000$ & $-(>5,000)$ & $-(>5,000)$ & $>1,000$ & $127,92(\mathrm{~N} / \mathrm{A})$ & 133, $181(\mathrm{~N} / \mathrm{A})$ & - \\
\hline 4-Aminobenzoic acid & NS & $>1,000$ & $-(>1,000)$ & $-(>1,000)$ & $>1,000$ & $88,102(\mathrm{~N} / \mathrm{A})$ & 100, 197 (N/A) & - \\
\hline
\end{tabular}

S, sensitizer; NS, non-sensitizer, N/A, not applicable; EC, effective concentration; RFI, relative fluorescence intensity; $h$-CLAT, human Cell Line Activation Test; CV75, 75\% cell viability.

a The test substances were coded and distributed to experimenters before the $h$-CLAT assays.

${ }^{b}$ Two independent runs were performed to determine the CV75 concentrations.

${ }^{c}$ The two highest RFI\% of two independent runs among the eight serially diluted concentrations that were tested.

${ }^{d}$ The EC150 for CD86 or the EC200 for CD54 is the average concentration from two independent runs at which the test substance induced an RFI of $150 \%$ or $200 \%$, respectively.

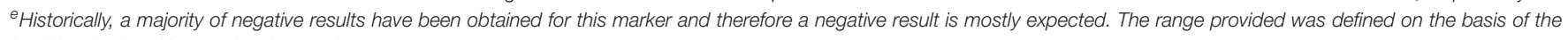
few historical positive results observed.

TABLE 2 | Prediction of the SS potency of silver and zinc oxide nanoparticles by h-CLAT assay.

\begin{tabular}{|c|c|c|c|c|c|c|c|}
\hline Nanoparticles & Size & Test run & $\begin{array}{c}\text { CV75 } \\
(\mu \mathrm{g} / \mathrm{ml})^{\mathrm{a}}\end{array}$ & $\begin{array}{l}\text { CD86 RFI (\%) } \\
\text { (EC150, } \\
\mu \mathrm{g} / \mathrm{ml})^{\mathrm{b}}\end{array}$ & $\begin{array}{l}\text { CD54 RFI (\%) } \\
\text { (EC200, }^{\mu \mathrm{g} / \mathrm{ml})^{\mathrm{b}}}\end{array}$ & $\begin{array}{c}+ \text { SS prediction }= \\
\text { CD86 } \geq 150 \% \text { and/or } \\
\text { CD54 } \geq 200 \%\end{array}$ & $\begin{array}{l}\text { Final prediction on } \\
\text { sensitization (positive if two } \\
\text { of three runs are }+ \text { ) }\end{array}$ \\
\hline \multirow[t]{3}{*}{ Silver } & $20 \mathrm{~nm}$ & $1 s t$ & 20.6 & $161(17)$ & $326(11)$ & + & Positive \\
\hline & & 2nd & & $174(11)$ & $285(8)$ & + & \\
\hline & & $3 r d$ & & 109 (N/A) & $248(17)$ & + & \\
\hline \multirow[t]{3}{*}{ Silver } & $50 \mathrm{~nm}$ & $1 s t$ & 21.6 & $146(\mathrm{~N} / \mathrm{A})$ & 1,205 (8) & + & Positive \\
\hline & & 2nd & & $109(\mathrm{~N} / \mathrm{A})$ & $169(\mathrm{~N} / \mathrm{A})$ & - & \\
\hline & & 3rd & & $181(8)$ & $880(6)$ & + & \\
\hline \multirow[t]{3}{*}{ Silver } & $80 \mathrm{~nm}$ & $1 s t$ & 20.8 & $260(8.0)$ & $10,006(8)$ & + & Positive \\
\hline & & 2nd & & $156(25)$ & $234(11)$ & + & \\
\hline & & $3 r d$ & & 249 (8) & $4,381(8)$ & + & \\
\hline \multirow[t]{3}{*}{ Zinc Oxide } & $30 \sim 40 \mathrm{~nm}$ & $1 s t$ & 25.8 & 217 (12) & $3,922(10)$ & + & Positive \\
\hline & & 2nd & & $263(13)$ & $4,622(11)$ & + & \\
\hline & & 3rd & & $360(9)$ & $4,721(11)$ & + & \\
\hline
\end{tabular}

SS, Skin Sensitizer; RFI, relative fluorescence intensity; $h$-CLAT, human Cell Line Activation Test; CV75, 75\% cell viability; EC, effective concentration; N/A, not applicable.

${ }^{a}$ Average CV75 of two independent runs.

${ }^{b}$ The highest RFI \% among the eight serially diluted concentrations that were tested.

concentrations resulting in quite low concentrations which could rarely cause a change in expression of markers. In concordance to our consideration, in a study, occlusive application of $10 \%$ aqueous sodium citrate solution for $20 \mathrm{~min}$ did not result in any immediate reactions or non-immunologic contact urticaria (Lahti, 2000).

Traditionally, micro-scale $\mathrm{ZnO}$ has been used in sunscreens owing to its ability to filter UVA and UVB radiations. Meanwhile, manufactures have shifted from micro formulation to nanoformulations as nano-sized $\mathrm{ZnO}$ improved the transparency and viscosity of sunscreens. The presence of $\mathrm{ZnO}$ in sunscreens makes skin a major route of exposure. Although $\mathrm{ZnO}$ was previously categorized as a non-toxic and non-skin irritant, size-dependent differential toxicity between micro and nanoscale materials has been observed (Patnaik, 2003; Franklin et al., 2007; Karlsson et al., 2009). It is further reported that $\mathrm{ZnO}$ nanoparticles were retained in the stratum corneum and accumulated in hair follicle roots or skin folds in humans (Zvyagin et al., 2008). According to studies, the release of metal ions during the dissolution of nanomaterials could cause toxicity; and cytotoxicity of metal oxides such as $\mathrm{ZnO}$ and $\mathrm{CuO} \mathrm{NP}$ is most likely due to their water-soluble ions (Cho et al., 2012; 


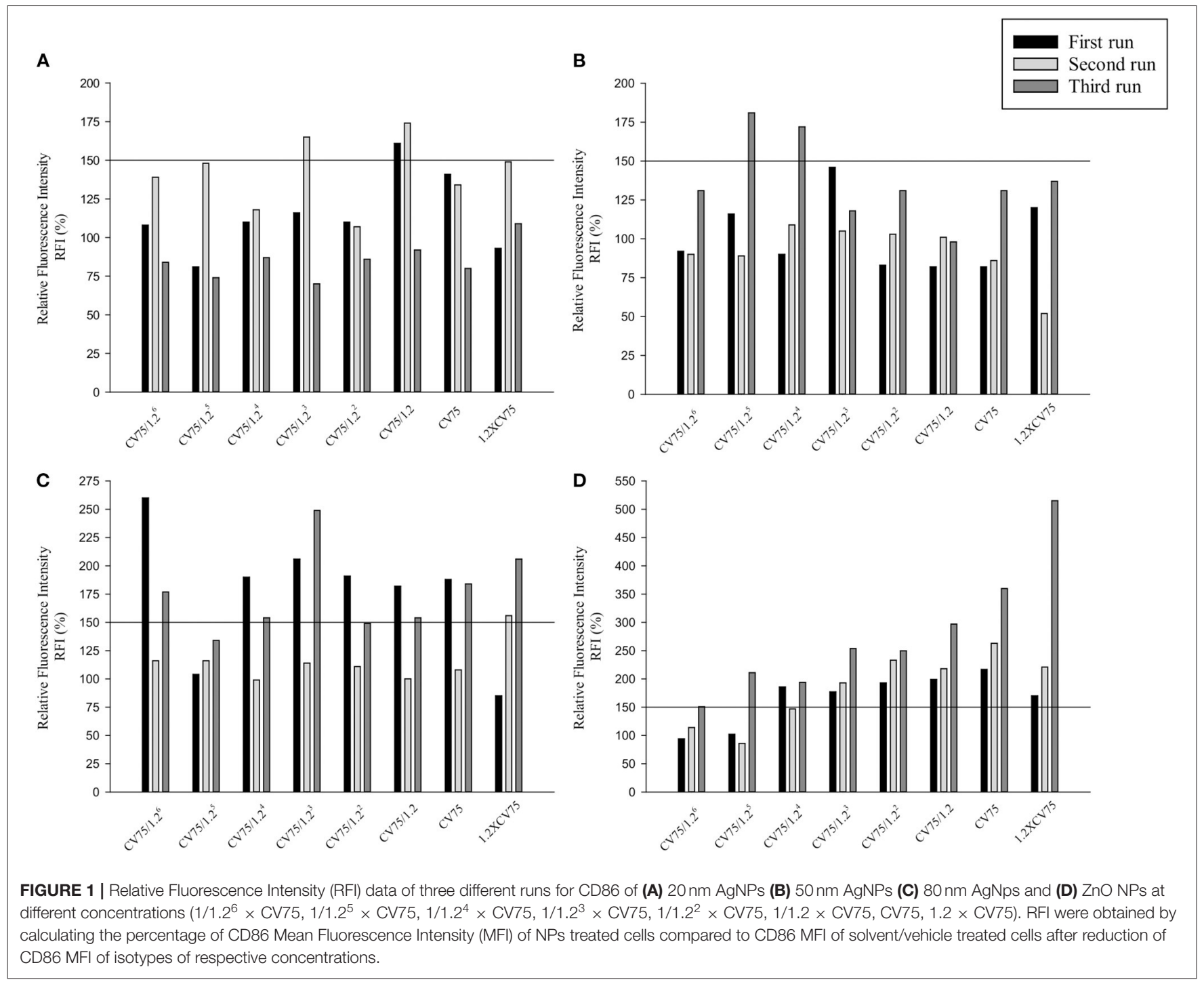

Jeong et al., 2018). Despite the fact that ions do not easily pass through cell membranes, toxic intracellular concentrations are achieved through a "Trojan horse" mechanism in which metal ions are released from NPs that cross the cell membrane (Cho et al., 2011; Hsiao et al., 2015). Cytotoxicity, oxidative stress due to $\mathrm{ZnO}$ is thought to be due to internalization and solubilization of $\mathrm{ZnO}$ inside the cell leading to increased intracellular $[\mathrm{Zn} 2+]$ levels, which disrupts the $\mathrm{Zn}$-dependent enzymes and transcription factors (Pandurangan and Kim, 2015). Nano-sized $\mathrm{ZnO}$ demonstrated a higher potential to induce toxicity and inflammation than micro-sized $\mathrm{ZnO}$ in THP-1 cells. Proinflammatory cytokines such as IL-1 $\beta$, IL-6, and TNF- $\alpha$ and inflammatory markers like intracellular adhesion molecule (ICAM)-1, IL-8, and monocytes chemoattractant protein(MCP)-1 were induced by $\mathrm{ZnO}$ nanopowder with size $<100 \mathrm{~nm}$ (Gojova et al., 2007; Sahu et al., 2014). One of the studies done with THP-1 macrophage showed that $\mathrm{ZnO}$ nanoparticles were able to activate similar pathways as viruses, they induced PAMP dependent pathways (TLR, RLR), cytokines (IFNs, TNF), and inflammasome secreting IL-1 $\beta$ (Poon et al., 2017). In primary human epidermal keratinocytes, $\mathrm{ZnO}$ internalized and induced cytotoxicity and genotoxicity, the range of cytotoxic dose ranged between 8 and $20 \mu \mathrm{g} / \mathrm{ml}$ (Sharma et al., 2011). In another study using THP-1 and MTT assay, $\mathrm{ZnO}$ NPs with a spherical diameter of $53.6 \mathrm{~nm}$ showed a much lower IC25 value of 2.33 and $5.54 \mu \mathrm{g} / \mathrm{ml}$ in two different participating laboratories however in our study the CV75 was higher than demonstrated in the previous studies. This could be due to the differences in the techniques used for the estimation of cell viability. ROS generation and induction of proinflammatory cytokines are linked to the skin sensitization potential of a chemical (Haas et al., 1992; Esser et al., 2012). Although ZnO nanopowder has been seen to induce both ROS generation and pro-inflammatory cytokines upregulations, thorough investigation on its skin sensitizing potential is lacking. The present study for the first time evaluated the skin sensitization 


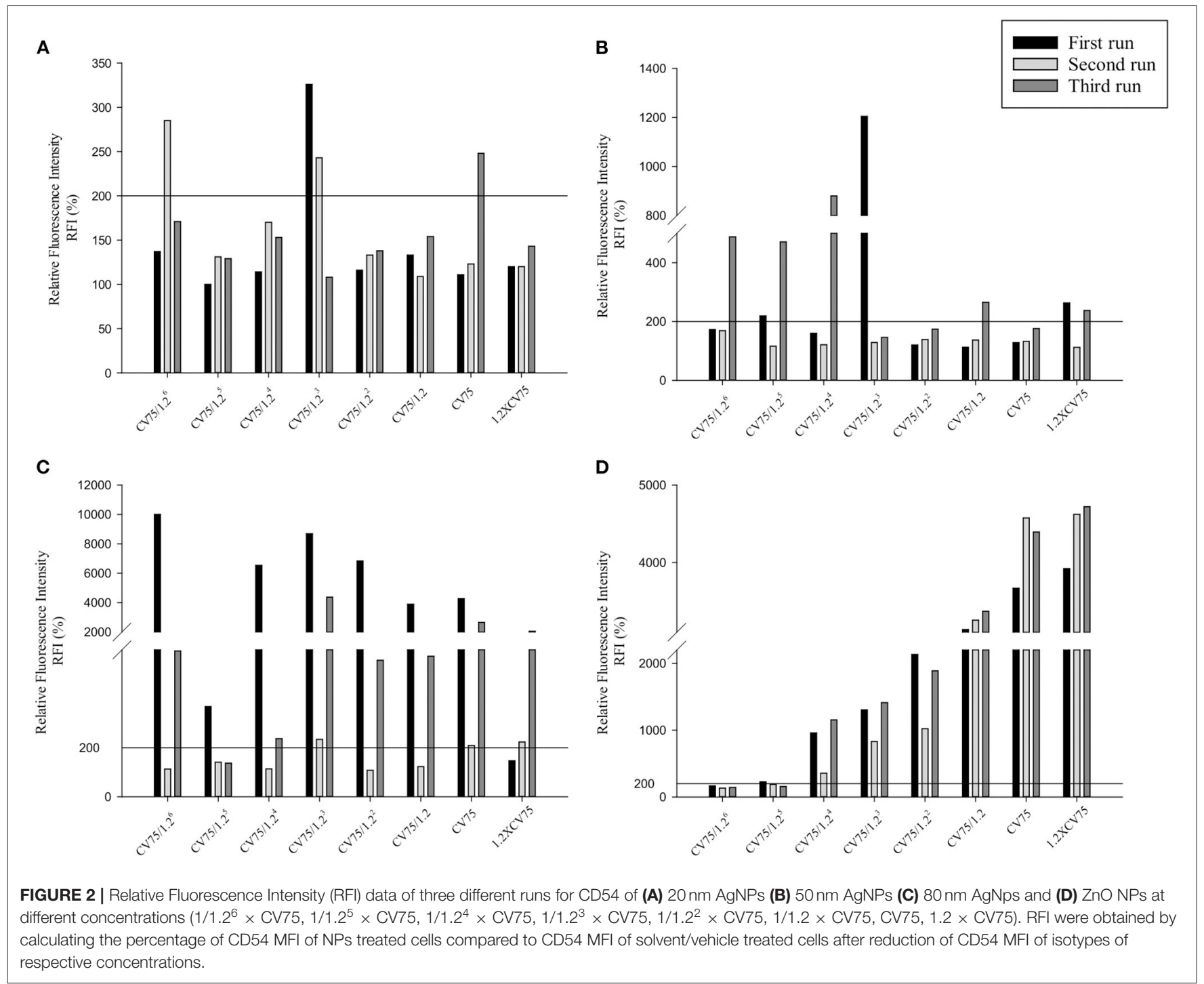

potency of $\mathrm{ZnO}$ nanopowder using h-CLAT. ZnO was classified as positive by h-CLAT assay since RFI for both CD86 and CD54 was higher than 150 and 200, respectively in all three runs.

Silver is considered a natural biocide. Ag NPs have shown high antimicrobial efficacy against bacteria, viruses, and other eukaryotic microorganisms and have been enormously used in consumer products such as deodorizing sprays, facial creams, clothing used for preventing body odors, baby wipes, etc (Gong et al., 2007). Ag NPs could be exposed to humans via dermal route during manufacturing or use of the products. Ag NPs in lower but detectable amounts can penetrate the intact skin and the absorption is increased in case of damaged skin, this makes consumers or manufacturers more vulnerable to skin-related diseases including skin sensitization. AgNPs toxicity, like $\mathrm{ZnO}$, could be attributed in part to high local intracellular concentrations of silver ions added to cells through the "Trojan Horse" mechanism (Park et al., 2010; Gliga et al., 2014; Helmlinger et al., 2016). Ag NPs have been studied for their toxicity in various cell lines and found to induce cytotoxicity and genotoxicity. Ag NPs damaged mitochondria and increased ROS causing DNA damage in normal lung fibroblasts (Asharani et al., 2008). AgNPs induced higher expression of IL- $1 \beta$ and TNF$\alpha$ at any tested concentration compared to its bulk counterpart $\mathrm{AgNO}_{3}$ including higher expression of cell surface markers such as ICAM-1, CD86, and IL-8 receptor alpha (CXCR1) in THP1 which are the signs of DC activation after the encounter to a skin sensitizer (Poon et al., 2017; OECD, 2018). Also, Ag NPs induced cytotoxicity dose-dependently and increased inflammatory proteins IL- $1 \beta$, IL-6, IL-8, and TNF- $\alpha$ in human epidermal keratinocytes (Samberg et al., 2010). In addition to dose-dependent toxicity, Ag NPs' uptake into cells is believed to be size-dependent. In THP-1 cells, Ag NPs uptake was in order $20>50=75 \mathrm{~nm}$ in culture media without fetal calf serum (FCS) and $50=75>20 \mathrm{~nm}$ in the presence of FCS (Kettler et al., 2016). In another study, HeLa cells favored intermediate size with uptake in the following order: $50>30>74>14>100$ on NPs number 
basis (Chithrani et al., 2006). In this study, independent of particle size, 20, 50, and $80 \mathrm{~nm} \mathrm{Ag} \mathrm{NPs} \mathrm{were} \mathrm{classified} \mathrm{as} \mathrm{positive}$ according to the h-CLAT prediction. Among three, $50 \mathrm{~nm} \mathrm{Ag} \mathrm{NP}$ was positive in two of three runs while the other two were positive in all three runs.

A few previous studies have classified topical application of Ag and $\mathrm{ZnO}$ NPs to be relatively safer regarding their skin toxicity. Application of agglomerated $\mathrm{ZnO}$ NPs in human volunteers for 5 days did not cause any local toxicity in viable epidermis owing to their inability to penetrate below skin furrows (Mohammed et al., 2019). Similarly, a study using various in vivo techniques concluded that $\mathrm{ZnO} \mathrm{NP}$ was relatively safe as it did not induce acute dermal toxicity, dermal irritation and corrosion, and skin sensitization (Kim et al., 2016). Furthermore, Ag NPs ranging from 7 to $20 \mathrm{~nm}$ in a gel formulation for topical application showed no sign of dermal toxicity in Sprague-Dawley rats (Jain et al., 2009). Our findings contradict these previous observations, as all the nanoparticles were positive in terms of expression of surface markers associated with the process of activation of monocytes and dendritic cells following exposure to sensitizers. Our method speculated these nanoparticles having the potential to cause skin sensitization however this method of assessing skin sensitizing potential addresses the third key event (KE3) of AOP for SS. Although h-CLAT assay has been adopted by the OECD, the method is accountable only after a particle encounters the dendritic cells irrespective of its skin penetration ability. OECD No. 256 sets out twelve separate defined approaches (DA) of Integrated Research Strategies (ITS) for the identification and classification of skin sensitizers using in silico and in vitro techniques based on four skin sensitization AOP KEs, such as " 2 out of 3 " and sequential testing strategies based on KEs1-3 and KE1 and 3. These approaches allow for a broad evaluation of exposure, skin penetration, metabolism, and key events (OECD, 2016). Further confirmatory assays addressing other KEs of AOP for SS need to be carried out to conclude them as potential skin sensitizers. Although the permeability of NPs through real skin is debatable and the stratum corneum acts as a barrier for

\section{REFERENCES}

Ahmad, U., Ahmad, Z., Khan, A. A., Akhtar, J., Singh, S. P., and Ahmad, F. J. (2018). Strategies in development and delivery of nanotechnology based cosmetic products. Drug Res. 68, 545-552. doi: 10.1055/a-0582-9372

Andres, E., Sá-Rocha, V. M., Barrichello, C., Haupt, T., Ellis, G., and Natsch, A. (2013). The sensitivity of the keratinoSensTM assay to evaluate plant extracts: a pilot study. Toxicol. Vitr. 27, 1220-1225. doi: 10.1016/j.tiv.2013.02.008

Asharani, P. V., Lian Wu, Y., Gong, Z., and Valiyaveettil, S. (2008). Toxicity of silver nanoparticles in zebrafish models. Nanotechnology 19:255102. doi: 10.1088/0957-4484/19/25/255102

Augustine, R., Kalarikkal, N., and Thomas, S. (2016). Electrospun PCL membranes incorporated with biosynthesized silver nanoparticles as antibacterial wound dressings. Appl. Nanosci. 6, 337-344. doi: 10.1007/s13204-015-0439-1

Bezerra, S. F., dos Santos Rodrigues, B., da Silva, A. C. G., de Ávila, R. I., Brito, H. R. G., Cintra, E. R., et al. (2021). Application of the adverse outcome pathway framework for investigating skin sensitization potential of nanomaterials using new approach methods. Contact Derm. 84, 67-74. doi: 10.1111/cod.13669

Carrouel, F., Viennot, S., Ottolenghi, L., Gaillard, C., and Bourgeois, D. (2020). Nanoparticles as anti-microbial, anti-inflammatory, and remineralizing agents penetration, the possibility of permeability of NPs from dermal products below the stratum corneum cannot be disregarded. The application of NPs containing dermal product in the sweating condition is supposed to facilitate the dissolution and increase solubilized metals below stratum corneum due to lower $\mathrm{pH}$ of the skin and also due to high prevalence of skin disease in the global population, sunscreen, cosmetics or dermal products could be applied to impaired skin because of an individual's skin condition or potentially because of prior damage of skin by environmental factors (Hay et al., 2014; Seth et al., 2017; Yoshioka et al., 2017; Holmes et al., 2020). Thus, findings from this study suggest the limited use of $\mathrm{ZnO}$ and Ag-NPs in dermal products to avoid probable skin sensitization. Moreover, the use of NPs' based products on damaged or fractured skin could lead to higher penetration of the skin by NPs causing a higher risk of skin sensitization.

\section{DATA AVAILABILITY STATEMENT}

The original contributions presented in the study are included in the article/supplementary material, further inquiries can be directed to the corresponding author/s.

\section{AUTHOR CONTRIBUTIONS}

All authors listed have made a substantial, direct and intellectual contribution to the work, and approved it for publication.

\section{FUNDING}

This study was supported by the National Institute of Environmental Research (2018), the National Research Foundation of Korea (Grant No. 2020R1I1A3-A04036509), and the educational training program for the management of information on the hazard and risk of chemical substances funded by the Ministry of Environment, Korea (entrusted to Korea Chemicals Management Association). in oral care cosmetics: a review of the current situation. Nanomaterials 10:140. doi: 10.3390/nano10010140

Chithrani, B. D., Ghazani, A. A., and Chan, W. C. W. (2006). Determining the size and shape dependence of gold nanoparticle uptake into mammalian cells. Nano Lett. 6, 662-668. doi: 10.1021/nl052396o

Cho, W. S., Duffin, R., Howie, S. E. M., Scotton, C. J., Wallace, W. A. H., MacNee, W., et al. (2011). Progressive severe lung injury by zinc oxide nanoparticles; the role of $\mathrm{Zn} 2+$ dissolution inside lysosomes. Part. Fibre Toxicol. 8, 1-16. doi: 10.1186/1743-8977-8-27

Cho, W. S., Duffin, R., Poland, C. A., Duschl, A., Oostingh, G. J., MacNee, W., et al. (2012). Differential pro-inflammatory effects of metal oxide nanoparticles and their soluble ions in vitro and in vivo; Zinc and copper nanoparticles, but not their ions, recruit eosinophils to the lungs. Nanotoxicology 6, 22-35. doi: 10.3109/17435390.2011.552810

Chung, H., Quan, H., Jung, D., Ravi, G., Cho, A., Kang, M. J., et al. (2018). Intraand inter-laboratory reproducibility and predictivity of the HaCaSens assay: a skin sensitization test using human keratinocytes, HaCaT. Toxicol. Vitr. 46, 304-312. doi: 10.1016/j.tiv.2017.10.018

Coecke, S., Balls, M., Bowe, G., Davis, J., Gstraunthaler, G., Hartung, T., et al. (2005). Guidance on good cell culture practice: a report of the second ECVAM 
task force on good cell culture practice. ATLA Altern. Lab. Anim. 33, 261-287. doi: $10.1177 / 026119290503300313$

Crosera, M., Bovenzi, M., Maina, G., Adami, G., Zanette, C., Florio, C., et al. (2009). Nanoparticle dermal absorption and toxicity: a review of the literature. Int. Arch. Occup. Environ. Health. 82, 1043-1055. doi: 10.1007/s00420-009-0458-x

Cross, S. E., Innes, B., Roberts, M. S., Tsuzuki, T., Robertson, T. A., and McCormick, P. (2007). Human skin penetration of sunscreen nanoparticles: invitro assessment of a novel micronized zinc oxide formulation. Skin Pharmacol. Physiol. 20, 148-154. doi: 10.1159/000098701

Esser, P. R., Wölfle, U., Dürr, C., von Loewenich, F. D., Schempp, C. M., Freudenberg, M. A., et al. (2012). Contact sensitizers induce skin inflammation via ROS production and hyaluronic acid degradation. PLOS ONE 7:41340. doi: 10.1371/journal.pone.0041340

EURL-ECVAM (2016). DB-ALM protocol n 158: Human Cell Line Activation Test (h-CLAT). Ispara: Joint Research Centre.

European Commission (2006). Regulation (EC) No 1907/2006 of the European Parliament and of the Council of 18 December 2006 concerning the Registration, Evaluation, Authorisation and Restriction of Chemicals (REACH), establishing a European Chemicals Agency, amending Directive 1999/45/EC and repealing Council Regulation (EEC) No 793/93 and Commission Regulation (EC) No1488/94 as well as Council Directive 76/769/ EEC and Commission Directives 91/155/EEC, 93/67/EEC, 93/105/EC and 2000/21/ EC. Off. J. Eur. Union. 396, 1-1355.

Franklin, N. M., Rogers, N. J., Apte, S. C., Batley, G. E., Gadd, G. E., and Casey, P. S. (2007). Comparative toxicity of nanoparticulate $\mathrm{ZnO}$, bulk $\mathrm{ZnO}$, and $\mathrm{ZnCl}_{2}$ to a freshwater microalga (Pseudokirchneriella subcapitata): the importance of particle solubility. Environ. Sci. Technol. 24, 8484-8490. doi: 10.1021/es071445r

Fytianos, G., Rahdar, A., and Kyzas, G. Z. (2020). Nanomaterials in cosmetics: recent updates. Nanomaterials 10:979. doi: 10.3390/nano10050979

Gliga, A. R., Skoglund, S., Odnevall Wallinder, I., Fadeel, B., and Karlsson, H. L. (2014). Size-dependent cytotoxicity of silver nanoparticles in human lung cells: the role of cellular uptake, agglomeration and Ag release. Part. Fibre Toxicol. 11, 1-17. doi: 10.1186/1743-8977-11-11

Gojova, A., Guo, B., Kota, R. S., Rutledge, J. C., Kennedy, I. M., and Barakat, A. I. (2007). Induction of inflammation in vascular endothelial cells by metal oxide nanoparticles: Effect of particle composition. Environ. Health Perspect. 115, 403-409. doi: 10.1289/ehp.8497

Gong, P., Li, H., He, X., Wang, K., Hu, J., Tan, W., et al. (2007). Preparation and antibacterial activity of Fe3O4@Ag nanoparticles. Nanotechnology 18:285604. doi: 10.1088/0957-4484/18/28/285604

Grundström, G., and Borrebaeck, C. A. K. (2019). Skin sensitization testingWhat's next? Int. J. Mol. Sci. 20:666. doi: 10.3390/ijms20030666

Gulson, B., Mccall, M., Korsch, M., Gomez, L., Casey, P., Oytam, Y., et al. (2010). Small amounts of zinc from zinc oxide particles in sunscreens applied outdoors are absorbed through human skin. Toxicol. Sci. 118, 140-149. doi: $10.1093 /$ toxsci/kfq243

Gulson, B., Wong, H., Korsch, M., Gomez, L., Casey, P., McCall, M., et al. (2012). Comparison of dermal absorption of zinc from different sunscreen formulations and differing UV exposure based on stable isotope tracing. Sci. Total Environ. 420, 313-318. doi: 10.1016/j.scitotenv.2011.12.046

Haas, J., Lipkow, T., Mohamadzadeh, M., Kolde, G., and Knop, J. (1992). Induction of inflammatory cytokines in murine keratinocytes upon in vivo stimulation with contact sensitizers and tolerizing analogues. Exp. Dermatol. 1, 76-83. doi: 10.1111/j.1600-0625.1992.tb00075.x

Hartung, T., Balls, M., Bardouille, C., Blanck, O., Coecke, S., Gstraunthaler, G., et al. (2002). Good cell culture practice: ECVAM good cell culture practice task force report 1. ATLA Altern. Lab. Anim. 30, 407-414. doi: $10.1177 / 026119290203000404$

Hay, R. J., Johns, N. E., Williams, H. C., Bolliger, I. W., Dellavalle, R. P., Margolis, D. J., et al. (2014). The global burden of skin disease in 2010: an analysis of the prevalence and impact of skin conditions. J. Invest. Dermatol. 134, 1527-1534. doi: 10.1038/jid.2013.446

Helmlinger, J., Sengstock, C., Groß-Heitfeld, C., Mayer, C., Schildhauer, T. A., Köller, M., et al. (2016). Silver nanoparticles with different size and shape: equal cytotoxicity, but different antibacterial effects. RSC Adv. 6, 18490-18501. doi: 10.1039/C5RA27836H

Henig, R. (2007). Our silver-coated future. On Earth Magazine September 1. Available online at: www.onearth.org/article/our-silver-coated-future
Holmes, A. M., Kempson, I., Turnbull, T., Paterson, D., Roberts, M. S., and Roberts, M. S. (2020). Penetration of zinc into human skin after topical application of nano zinc oxide used in commercial sunscreen formulations. ACS Appl. Bio Mater. 3, 3640-3647. doi: 10.1021/acsabm.0c00280

Hsiao, I. L., Hsieh, Y. K., Wang, C. F., Chen, I. C., and Huang, Y. J. (2015). Trojanhorse mechanism in the cellular uptake of silver nanoparticles verified by direct intra- and extracellular silver speciation analysis. Environ. Sci. Technol. 49, 3813-3821. doi: 10.1021/es504705p

Huy, T. Q., Huyen, P. T. M., Le, A.-T., and Tonezzer, M. (2019). Recent advances of silver nanoparticles in cancer diagnosis and treatment. Anticancer. Agents Med. Chem. 20, 1276-1287. doi: 10.2174/1871520619666190710121727

Jain, J., Arora, S., Rajwade, J. M., Omray, P., Khandelwal, S., and Paknikar, K. M. (2009). Silver nanoparticles in therapeutics: development of an antimicrobial gel formulation for topical use. Mol. Pharm. 6, 1388-1401. doi: $10.1021 / \mathrm{mp} 900056 \mathrm{~g}$

Jeong, J., Kim, S. H., Lee, S., Lee, D. K., Han, Y., Jeon, S., et al. (2018). Differential contribution of constituent metal ions to the cytotoxic effects of fast-dissolving metal-oxide nanoparticles. Front. Pharmacol. 9:15. doi: 10.3389/fphar.2018.00015

Joo, S. J., Gautam, R., Lee, J. H., Kim, H. J., Yang, S. J., Jo, J. H., et al. (2019). Prediction of the skin sensitization potential of polyhexamethylene guanidine phosphate, oligo(2-(2-ethoxy)ethoxyethyl) guanidinium chloride, triclosan, and mixtures of these compounds with the excipient propylene glycol through the local lymph node assay. Toxicol. Ind. Health 35, 638-646. doi: $10.1177 / 0748233719884853$

Jung, Y. S., Kato, R., and Tsuchiya, T. (2011). Biodegradable polymers induce CD54 on THP-1 cells in skin sensitization test. Int. J. Biomater. 2011:424571. doi: $10.1155 / 2011 / 424571$

Karlsson, H. L., Gustafsson, J., Cronholm, P., and Möller, L. (2009). Sizedependent toxicity of metal oxide particles-A comparison between nanoand micrometer size. Toxicol. Lett. 188, 112-118. doi: 10.1016/j.toxlet.2009. 03.014

Kaul, S., Gulati, N., Verma, D., Mukherjee, S., and Nagaich, U. (2018). Role of nanotechnology in cosmeceuticals: a review of recent advances. J. Pharm. 2018:3420204. doi: 10.1155/2018/3420204

Kettler, K., Giannakou, C., de Jong, W. H., Hendriks, A. J., and Krystek, P. (2016). Uptake of silver nanoparticles by monocytic THP-1 cells depends on particle size and presence of serum proteins. J. Nanoparticle Res. 18, 1-9. doi: 10.1007/s11051-016-3595-7

Khan, S. U., Saleh, T. A., Wahab, A., Khan, M. H. U., Khan, D., Khan, W. U., et al. (2018). Nanosilver: new ageless and versatile biomedical therapeutic scaffold. Int. J. Nanomed. 13:733. doi: 10.2147/IJN.S153167

Kim, K. B., Kim, Y. W., Lim, S. K., Roh, T. H., Bang, D. Y., Choi, S. M., et al. (2017). Risk assessment of zinc oxide, a cosmetic ingredient used as a UV filter of sunscreens. J. Toxicol. Environ. Health B Crit. Rev. 20, 155-182. doi: 10.1080/10937404.2017.1290516

Kim, S., Lee, D. H., Lee, J. H., Yang, J., Shin, H., Lee, J., et al. (2020). Carbon nanotubes using alternative in vitro and in vivo assays. Toxics 8:122. doi: $10.3390 /$ toxics 8040122

Kim, S., Lee, S. Y., and Cho, H. J. (2017). Doxorubicin-wrapped zinc oxide nanoclusters for the therapy of colorectal adenocarcinoma. Nanomaterials 7:354. doi: 10.3390/nano7110354

Kim, S. H., Heo, Y., Choi, S. J., Kim, Y. J., Kim, M. S., Kim, H., et al. (2016). Safety evaluation of zinc oxide nanoparticles in terms of acute dermal toxicity, dermal irritation and corrosion, and skin sensitization. Mol. Cell. Toxicol. 12, 93-99. doi: 10.1007/s13273-016-0012-3

Kim, S. H., Lee, D. H., Lee, J. H., Yang, J. Y., Seok, J. H., Jung, K., et al. (2021a). Evaluation of the skin sensitization potential of metal oxide nanoparticles using the ARE-Nrf2 luciferase KeratinoSensTM assay. Toxicol. Res. 37, 277-284. doi: $10.1007 / s 43188-020-00071-0$

Kim, S. H., Lee, J. H., Jung, K., Yang, J. Y., Shin, H. S., Lee, J. P., et al. (2021b). Copper and cobalt ions released from metal oxide nanoparticles trigger skin sensitization. Front. Pharmacol. 12:627781. doi: 10.3389/fphar.2021.62 7781

Lahti, A. (2000). "Non-immunologic contact urticaria," in Handbook of Occupational Dermatology, eds L. Kanerva, J. E. Wahlberg, P. Elsner, and H. I. Maibach (Berlin, Heidelberg: Springer Berlin Heidelberg), 221-224. doi: 10.1007/978-3-662-07677-4_26 
Larese, F. F., D’Agostin, F., Crosera, M., Adami, G., Renzi, N., Bovenzi, M., et al. (2009). Human skin penetration of silver nanoparticles through intact and damaged skin. Toxicology 255, 33-37. doi: 10.1016/j.tox.2008.09.025

Lee, J. H., Cho, A. R., Gautam, R., Kim, Y. G., Shin, S. J., Song, E. S., et al. (2019). Prediction of the skin sensitization potential of didecyldimethylammonium chloride and 3,7-dimethyl-2,6-octadienal and mixtures of these compounds with the excipient ethylene glycol through the human cell line activation test and the direct peptide reactivity assay. Toxicol. Ind. Health 35, 507-519. doi: $10.1177 / 0748233719869514$

Liu, P., Guan, R., Ye, X., Jiang, J., Liu, M., Huang, G., et al. (2011). Toxicity of nanoand micro-sized silver particles in human hepatocyte cell line L02. J. Phys. Conf. Ser. 304:012036. doi: 10.1088/1742-6596/304/1/012036

Mihranyan, A., Ferraz, N., and Strømme, M. (2012). Current status and future prospects of nanotechnology in cosmetics. Prog. Mater. Sci. 57, 875-910. doi: 10.1016/j.pmatsci.2011.10.001

Mishra, P. K., Mishra, H., Ekielski, A., Talegaonkar, S., and Vaidya, B. (2017). Zinc oxide nanoparticles: a promising nanomaterial for biomedical applications. Drug Discov. Today 22, 1825-1834. doi: 10.1016/j.drudis.2017.08.006

Mohammed, Y. H., Holmes, A., Haridass, I. N., Sanchez, W. Y., Studier, H., Grice, J. E., et al. (2019). Support for the safe use of zinc oxide nanoparticle sunscreens: lack of skin penetration or cellular toxicity after repeated application in volunteers. J. Invest. Dermatol. 139, 308-315. doi: 10.1016/j.jid.2018.08.024

Monteiro-Riviere, N. A., Wiench, K., Landsiedel, R., Schulte, S., Inman, A. O., and Riviere, J. E. (2011). Safety evaluation of sunscreen formulations containing titanium dioxide and zinc oxide nanoparticles in UVB sunburned skin: an in vitro and in vivo study. Toxicol. Sci. 123, 264-280. doi: 10.1093/toxsci/kfr148

Murphy, M., Ting, K., Zhang, X., Soo, C., and Zheng, Z. (2015). Current development of silver nanoparticle preparation, investigation, and application in the field of medicine. J. Nanomater. 2015:12. doi: 10.1155/2015/696918

Noronha, V. T., Paula, A. J., Durán, G., Galembeck, A., Cogo-Müller, K., FranzMontan, M., et al. (2017). Silver nanoparticles in dentistry. Dent. Mater. 33, 1110-1126. doi: 10.1016/j.dental.2017.07.002

OECD (2014), The Adverse Outcome Pathway for Skin Sensitisation Initiated by Covalent Binding to Proteins, OECD Series on Testing and Assessment, No. 168. Paris: OECD Publishing.

OECD (2016). Guidance Document on the Reporting of Defined Approaches and Individual Information Sources To Be Used Within Integrated Approaches to Testing and Assessment (IATA) for Skin Sensitization, OECD series on Testing and Assessment, No.256. Paris: OECD Publishing.

OECD (2018). Test No. 442E: In Vitro Skin Sensitisation: In Vitro Skin Sensitisation Assays Addressing the Key Event on Activation of Dendritic Cells on the Adverse Outcome Pathways for Skin Sensitisation, OECD Guidelines for the Testing of Chemicals, Section 4. Paris: OECD Publishing.

Osmond, M. J., and McCall, M. J. (2010). Zinc oxide nanoparticles in modern sunscreens: an analysis of potential exposure and hazard. Nanotoxicology 4, 15-41. doi: 10.3109/17435390903502028

Pandurangan, M., and Kim, D. H. (2015). In vitro toxicity of zinc oxide nanoparticles: a review. J. Nanoparticle Res. 17, 1-8. doi: 10.1007/s11051-015-2958-9

Park, E. J., Yi, J., Kim, Y., Choi, K., and Park, K. (2010). Silver nanoparticles induce cytotoxicity by a trojan-horse type mechanism. Toxicol. Vitr. 24, 872-878. doi: 10.1016/j.tiv.2009.12.001

Pastrana, H., Avila, A., and Tsai, C. S. J. (2018). Nanomaterials in cosmetic products: the challenges with regard to current legal frameworks and consumer exposure. Nanoethics 12, 132-137. doi: 10.1007/s11569-018-0317-x

Patnaik, P. (2003). Handbook of Inorganic Chemicals Vol. 529. New York, NY: McGraw-Hill.

Poon, W. L., Alenius, H., Ndika, J., Fortino, V., Kolhinen, V., Meščeriakovas, A., et al. (2017). Nano-sized zinc oxide and silver, but not titanium dioxide, induce innate and adaptive immunity and antiviral response in differentiated THP-1 cells. Nanotoxicology 11, 936-951. doi: 10.1080/17435390.2017.1382600

Prach, M., Stone, V., and Proudfoot, L. (2013). Zinc oxide nanoparticles and monocytes: impact of size, charge and solubility on activation status. Toxicol. Appl. Pharmacol. 266, 19-26. doi: 10.1016/j.taap.2012.10.020

Rai, M., Ingle, A. P., Paralikar, P., Gupta, I., Medici, S., and Santos, C. A. (2017). Recent advances in use of silver nanoparticles as antimalarial agents. Int. J. Pharm. 526, 254-270. doi: 10.1016/j.ijpharm.2017.04.042
Rancan, F., Gao, Q., Graf, C., Troppens, S., Hadam, S., Hackbarth, S., et al. (2012). Skin penetration and cellular uptake of amorphous silica nanoparticles with variable size, surface functionalization, and colloidal stability. ACS Nano. 6, 6829-6842. doi: 10.1021/nn301622h

Sahu, D., Kannan, G. M., Tailang, M., and Vijayaraghavan, R. (2016). In vitro cytotoxicity of nanoparticles: a comparison between particle size and cell type. J. Nanosci. 2016, 1-9. doi: 10.1155/2016/4023852

Sahu, D., Kannan, G. M., and Vijayaraghavan, R. (2014). Size-dependent effect of zinc oxide on toxicity and inflammatory potential of human monocytes. J. Toxicol. Environ. Heal. A. 77, 177-191. doi: 10.1080/15287394.2013.853224

Samberg, M. E., Oldenburg, S. J., and Monteiro-Riviere, N. A. (2010). Evaluation of silver nanoparticle toxicity in skin in vivo and keratinocytes in vitro. Environ. Health Perspect. 118, 407-413. doi: 10.1289/ehp.0901398

Seil, J. T., and Webster, T. J. (2012). Antimicrobial applications of nanotechnology: methods and literature. Int. J. Nanomed. 7:2767. doi: 10.2147/IJN.S24805

Selvam, K. P., Nagahata, T., Kato, K., Koreishi, M., Nakamura, T., Nakamura, Y., et al. (2020). Synthesis and characterization of human skin-compatible conductive flexible cellulose carbon nanohorn sheets for human tissue application. Biomater. Res. 24:18. doi: 10.21203/rs.3.rs-34961/v1

Seth, D., Cheldize, K., Brown, D., and Freeman, E. F. (2017). Global Burden of Skin Disease: Inequities and Innovations. Curr. Dermatol. 6, 204-210. doi: 10.1007/s13671-017-0192-7

Settivari, R. S., Gehen, S. C., Amado, R. A., Visconti, N. R., Boverhof, D. R., and Carney, E. W. (2015). Application of the KeratinoSensTM assay for assessing the skin sensitization potential of agrochemical active ingredients and formulations. Regul. Toxicol. Pharmacol. 72, 350-360. doi: 10.1016/j.yrtph.2015.05.006

Settivari, R. S., Rowlands, J. C., Wilson, D. M., Arnold, S. M., and Spencer, P. J. (2017). "Application of evolving computational and biological platforms for chemical safety assessment," in A Comprehensive Guide to Toxicology in Nonclinical Drug Development, ed A. S. Faqi (New York, NY: Academic Press/Elsevier), 843-873. doi: 10.1016/B978-0-12-803620-4.00032-3

Sharma, V., Singh, S. K., Anderson, D., Tobin, D. J., and Dhawan, A. (2011). Zinc oxide nanoparticle induced genotoxicity in primary human epidermal keratinocytes. J. Nanosci. Nanotechnol. 11, 3782-3788. doi: 10.1166/jnn.2011.4250

Shi, L. E., Li, Z. H., Zheng, W., Zhao, Y. F., Jin, Y. F., and Tang, Z. X. (2014). Synthesis, antibacterial activity, antibacterial mechanism and food applications of $\mathrm{ZnO}$ nanoparticles: a review. Food Addit. Contam. A. 31, 173-186. doi: 10.1080/19440049.2013.865147

Sirelkhatim, A., Mahmud, S., Seeni, A., Kaus, N. H. M., Ann, L. C., Bakhori, S. K. M., et al. (2015). Review on zinc oxide nanoparticles: antibacterial activity and toxicity mechanism. Nano Micro Lett. 7, 219-242. doi: 10.1007/s40820-015-0040-x

Surekha, P., Kishore, A. S., Srinivas, A., Selvam, G., Goparaju, A., Reddy, P. N., et al. (2012). Repeated dose dermal toxicity study of nano zinc oxide with sprague-dawley rats. Cutan. Ocul. Toxicol. 31, 26-32. doi: 10.3109/15569527.2011.595750

Verbič, A., Gorjanc, M., and Simončič, B. (2019). Zinc oxide for functional textile coatings: recent advances. Coatings 9, 17-23. doi: 10.3390/coatings90 90550

Vigneshwaran, N., Kathe, A. A., Varadarajan, P. V., Nachane, R. P., and Balasubramanya, R. H. (2007). Functional finishing of cotton fabrics using silver nanoparticles. J. Nanosci. Nanotechnol. 7, 1893-1897. doi: 10.1166/jnn.2007.737

Wang, S. Q., and Tooley, I. R. (2011). Photoprotection in the era of nanotechnology. Semin. Cutan. Med. Surg. 30, 210-213. doi: 10.1016/j.sder.2011.07.006

Wijnhoven, S. W. P., Peijnenburg, W. J. G. M., Herberts, C. A., Hagens, W. I., Oomen, A. G., Heugens, E. H. W., et al. (2009). Nano-silver - a review of available data and knowledge gaps in human and environmental risk assessment. Nanotoxicology 3, 109-138. doi: 10.1080/17435390902 725914

Wu, J., Liu, W., Xue, C., Zhou, S., Lan, F., Bi, L., et al. (2009). Toxicity and penetration of $\mathrm{TiO}_{2}$ nanoparticles in hairless mice and porcine skin after subchronic dermal exposure. Toxicol. Lett. 191, 1-8. doi: 10.1016/j.toxlet.2009.05.020 
Yang, S., Heo, Y., Gautam, R., Lee, J., Maharjan, A., Jo, J., et al. (2021). Prediction of the skin sensitization potential of polyhexamethylene guanidine and triclosan and mixtures of these compounds with the excipient propylene glycol through the human cell line activation test. Toxicol. Ind. Health. 37, 1-8. doi: 10.1177/074823372097 4131

Yoshioka, Y., Kuroda, E., Hirai, T., Tsutsumi, Y., and Ishii, K. J. (2017). Allergic responses induced by the immunomodulatory effects of nanomaterials upon skin exposure. Front. Immunol. 8:169. doi: 10.3389/fimmu.2017.00169

Zhang, Y., Nayak, T., Hong, H., and Cai, W. (2013). Biomedical applications of zinc oxide nanomaterials. Curr. Mol. Med. 13, 1633-1645. doi: 10.2174/1566524013666131111130058

Zvyagin, A. V., Zhao, X., Gierden, A., Sanchez, W., Ross, J. A., and Roberts, M. S. (2008). Imaging of zinc oxide nanoparticle penetration in human skin in vitro and in vivo. J. Biomed. Opt. 13:064031. doi: 10.1117/1.3 041492

Conflict of Interest: The authors declare that the research was conducted in the absence of any commercial or financial relationships that could be construed as a potential conflict of interest.

Copyright (c) 2021 Gautam, Yang, Maharjan, Jo, Acharya, Heo and Kim. This is an open-access article distributed under the terms of the Creative Commons Attribution License (CC BY). The use, distribution or reproduction in other forums is permitted, provided the original author(s) and the copyright owner(s) are credited and that the original publication in this journal is cited, in accordance with accepted academic practice. No use, distribution or reproduction is permitted which does not comply with these terms. 